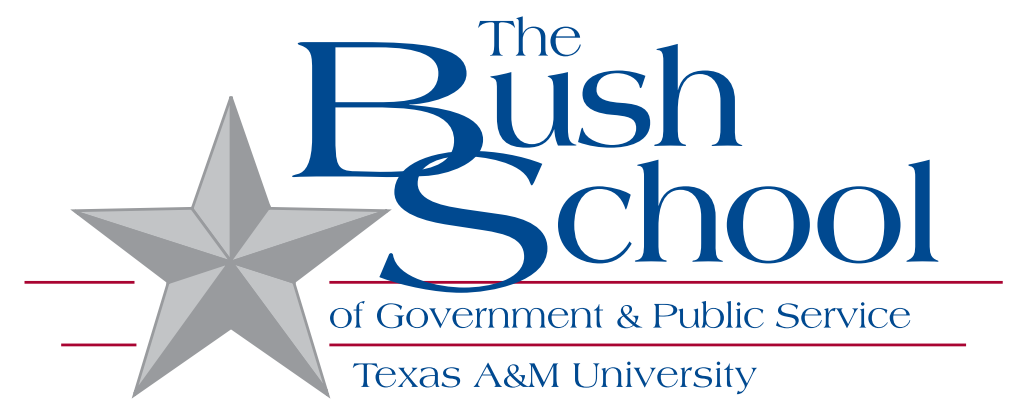

\title{
FROM THE OBSOLESCING BARGAIN TO THE POLITICAL BARGAINING MODEL
}

\author{
Lorraine Eden
}

Professor, Department of Management and the George Bush School of Government and Public Service

Texas A\&M University

Stefanie Lenway

Professor, Department of Strategic Management

University of Minnesota

Douglas A. Schuler

Associate Professor, Department of Management

Rice University

January 2004

Bush School Working Paper \# 403

No part $\mathrm{f}$ the Bush School transmission may be copied, downloaded, stored, further transmitted, transferred, distributed, altered, or otherwise used, in an form or by an means, except: (1) one stored copy for personal use, non-commercial use, or (2) prior written consent. No alterations of the transmission or removal of copyright notices is permitted. 


\title{
FROM THE OBSOLESCING BARGAIN TO THE POLITICAL BARGAINING MODEL
}

\author{
Lorraine Eden \\ Professor \\ Department of Management and the George Bush School of Government and Public Service \\ Texas A\&M University \\ TAMU 4221, College Station, TX 77843-4221 \\ Phone: 979/862-4053 Fax: 979/845-9641 Email: leden@tamu.edu \\ Stefanie Lenway \\ Professor \\ Department of Strategic Management \\ University of Minnesota \\ 3-365 CSOM, 321 - 19th Ave. S., Minneapolis, MN 55455 \\ Phone: 612-624-1343 Fax: 612-626-1316 Email: slenway@csom.umn.edu \\ Douglas A. Schuler \\ Associate Professor \\ Department of Management \\ Rice University \\ Rm. 348, MS-531, P.O. Box 2932, Houston, Texas 77252-2932 \\ Phone: 713 348-5472 Fax: E-mail: schuler@rice.edu
}

Presented at the workshop "International Business \& Government Relations in the $21^{\text {st }}$ Century"

Thunderbird, Phoenix, AZ, January 5, 2004

Acknowledgements: Some of the ideas in this paper were first developed in Eden and Molot (2002). We

thank Steve Kobrin and the participants at the "International Business \& Government Relations in the $21^{\text {st }}$

Century” workshop for helpful comments on an earlier draft of this paper.

(c) Lorraine Eden, Stefanie Lenway and Douglas Schuler. All rights reserved 


\title{
FROM THE OBSOLESCING BARGAIN TO THE POLITICAL BARGAINING MODEL
}

\begin{abstract}
The widely held view among international business (IB) scholars is that the obsolescing bargain model (OBM) has outlived its usefulness. MNEs and host country governments seldom negotiate entry conditions (except at the local level in terms of financial incentives), and entry bargains if they occur seldom obsolesce. We argue, in this paper, that the essential elements of the obsolescing bargain model can and should be retained. OBM does have long term usefulness as a theoretical model of MNE-state relations once the twin emphases on 'entry' and 'obsolescing' are removed. Instead, we propose that IB scholars should revitalize OBM by reconceptualizing it as a political bargaining model (PBM). In our political bargaining model, MNE-state relations are modeled as iterative political bargains negotiated between MNEs and governments over a wide variety of government policies at the industry level. We argue PBM is a powerful tool for analyzing MNE-state relations, which includes OBM as a special case.
\end{abstract}




\section{FROM THE OBSOLESCING BARGAIN TO THE POLITICAL BARGAINING MODEL}

\section{Introduction}

The best-known model of relations between multinational enterprises and host country governments is the obsolescing bargain model (OBM), first developed by Raymond Vernon in Sovereignty at Bay (1971). OBM explains the changing nature of bargaining relations between a multinational enterprise (MNE) and host country government (HC) as a function of goals, resources and constraints on both parties (Vernon, 1971, 1977; Kobrin, 1987; Brewer, 1992; Grosse \& Behrman, 1992; Grosse, 1996). In OBM, the initial bargain favors the MNE, but relative bargaining power shifts to the host country government over time as MNE assets are transformed into hostages. Once bargaining power shifts from the MNE to the host country, the government imposes more conditions on the MNE, ranging from higher taxes to complete expropriation of MNE assets. Thus, the original bargain obsolesces, giving OBM its name. Originally applied as an explanation for widespread expropriation and nationalization in the 1970s of MNE natural-resource subsidiaries located in developing countries (Vernon, 1977), OBM was later tested in other situations such as manufacturing MNEs and developed HCs, with much weaker results (Kobrin, 1987).

The now widely held view among international business scholars is that the obsolescing bargain model has outlived its usefulness. The many case studies testing the model suggest that MNEs were able to retain relative bargaining power and prevent opportunistic behavior by HC governments so the bargains, in practice, seldom obsolesced. In addition, today, few governments restrict inward FDI, either in the form of screening or performance requirements, so that little formal bargaining over entry occurs between MNEs and host governments. To the extent entry bargaining does occur, it is mostly at the local level as cities compete in so-called 'locational tournaments' to attract new investments. Thus, host governments have shifted from 'red tape' to 'red carpet' treatment of foreign MNEs. MNE-government relations are now seen as cooperative, not conflictual (Dunning, 1993a; Stopford, 1994; Luo, 2001). As a result, there appear to be few areas where OBM applies. 
The purpose of this paper is to refute this view. We argue that the essential elements of the obsolescing bargain model can and should be retained. OBM does have long term usefulness as a theoretical model of MNE-state relations once the twin emphases on 'entry' and 'obsolescing' are removed. Instead, we propose that IB scholars should revitalize OBM by reconceptualizing OBM as a political bargaining model (PBM). In our political bargaining model, MNE-state relations are modeled as iterative political bargains negotiated between MNEs and governments over a wide variety of government policies at the industry level.

Our new PBM updates the obsolescing bargain model by incorporating recent insights from the liability of foreignness, transaction cost economics and the resource based view literatures. We argue that ‘obsolescing bargain' can be reconceptualized as 'political bargaining' if, first, we broaden the issue area from a focus on ownership shares and recognize that firms and governments engage in iterative bargaining over a wide variety of government policies at the industry level. MNE entrants want not only to maintain the original bargain but also search for new bargains that will enhance their competitive position. Obtaining favorable outcomes in these public policy debates is critically important to firm competitiveness and performance. Second, even if MNE-state relations are cooperative and not conflictual in nature, democratic governments must also take into account the interests of other stakeholders (e.g., consumers, labor groups, nongovernmental organizations) and commitments (e.g., membership in international organizations, bilateral and regional accords) so that, in practice, MNEs must bargain for favorable public policies. Many of these favorable policies may also contribute to host country economic growth and have the effect of creating more resources for both the company and the country. Lastly, the essential insight of OBM -- that bargaining processes and outcomes depend on the parties' goals, resources and constraints - can and should be retained in PBM, even if MNE-state bargains do not obsolesce. PBM is therefore a powerful tool for analyzing MNE-state relations, which includes OBM as a special case. 


\section{The Obsolescing Bargain Model}

OBM explains bargaining relations between an MNE and a host country as a function of goals, resources and constraints on each party (Vernon, 1971; Moran, 1985; Kobrin, 1987; Brewer, 1992; Grosse \& Behrman, 1992; Vachani, 1995; Grosse, 1996).

In the original model, the goals of the MNE and $\mathrm{HC}$ are assumed to be conflicting. Even though their goals are assumed to conflict, OBM assumes that bargaining is a positive sum game such that both parties will voluntarily bargain and achieve absolute gains. Relative gains, however, will be positively related to relative bargaining power: the greater one party's relative bargaining power, the greater that party's relative share of the gains. Absolute gains refer to the dollar magnitude of gains realized by one party; relative gains to each party's share of the total gains. Alternatively, absolute gains can be interpreted as how closely each party comes to achieving its first best goals; relative gains by comparing the two parties' success rates. The OBM literature suggests that the outcome should favor the party with the stronger resources, higher issue salience, weaker constraints and greater coercive power.

In OBM, relative bargaining power is assumed to initially favor the MNE. Because the MNE can invest in several locations (has other alternatives) and is therefore highly mobile or has capabilities and resources to extract raw materials that the host country does not have, the HC has to offer locational incentives to attract inward FDI. The initial bargain then obsolesces over time. Once the MNE has made sector-specific investments in the host country, these resources can be held hostage by an opportunistic HC. The longer the MNE is in the host country, the more likely it is that the government's perception of the benefit-cost ratio offered by the MNE falls, particularly if the investment turns out to be much more profitable than either the MNE or the $\mathrm{HC}$ anticipated and there are large profit remittances to the affiliate's parent firm. At the same time, technological spillovers and economic development encourage the emergence of local competitors, so that the HC becomes less resource dependent on the MNE over time as there are more likely to be local firms that could replace the MNE, assuming that all the resources and capabilities to create a product exist in the HC. If the host government's perception of the benefitcost ratio turns negative, the obsolescing bargain model hypothesized that the HC would demand more 
commitments from the MNE, causing the original bargain to obsolesce.

The wave of nationalizations in the early 1970s are used as real-world evidence of MNE-HC obsolescing bargains, but even in vertically integrated, resource-intensive industries, there is some evidence that MNEs have been able to protect their bargains. For example, Theodore Moran’s 1973 study of the Chilean copper industry found that the US multinational Kennecott developed domestic and transnational alliances which, when the firm was nationalized by the Chilean government in 1971, were successful in getting Kennecott nearly full compensation for its investments (Moran, 1973). Anaconda, another US MNE that had not developed any domestic alliances, was nationalized without any compensation. Moran concluded that resource-intensive industries could reduce the probability of an obsolescing bargain by reducing their own risk exposure and raising the costs to the HC of opportunistic behavior. As a second example, Jenkins’ 1986 study of the National Energy Policy in Canada found that the oil MNEs were able to defeat the National Energy Program by enlisting the US government on their behalf, shifting their oil rigs outside of Canada and canceling new investments (Jenkins, 1986). Moran (1985) also provides several rich case studies.

In manufacturing industries, MNE-HC bargains are expected to be less prone to obsolescence because MNE investments tend to be smaller and more mobile, and the MNE's knowledge-based firm specific advantages (FSAs) more difficult to copy (Kobrin, 1987). If the MNE can supply the HC with a stream of new investments (thus, keeping the country dependent on the MNE for new technology, products and/or access to export markets, and improving the government's perception of the value added from FDI), the bargain need not obsolesce. The MNE can ward off obsolescence by forming strategic alliances with local firms that have desired resources and/or capabilities, diversifying activities outside the host country by dispersing manufacturing sites across several countries to reduce the probability of being held hostage, and offering more benefits to the host government, such as involving the government in the business venture (Grosse \& Behrman, 1992).

Vachani’s study of nationalizations of foreign MNE investments by the Indian government of US, British and European subsidiaries over the 1973-85 period suggested that bargaining outcomes should be 
broken into two components (Vachani, 1995). He argued for differentiating between static bargaining success (the outcome of any one particular negotiation) from dynamic bargaining success (the long-run trend in outcomes over several negotiations), on the grounds that factors important for one might not be important for the other. Over the longer term, the MNE's FSAs in the form of technology intensity and size of investment were positively related to the MNE's ability to prevent the bargain from obsolescing; that is, with dynamic bargaining success.

Using percent of ownership as a measure of bargaining success, Kobrin (1987) found evidence that suggested the MNE-HC bargain did not obsolesce for manufacturing MNEs, particularly in high technology sectors, supporting Vachani's argument. Bennett and Sharpe (1979), in their study of bargaining between the Mexican government and foreign automotive MNEs, found that the Mexican government's bargaining power was strongest at time of entry because the MNEs desired access to the Mexican market. Once the MNEs had become integrated into the Mexican economy and developed strong relationships with local upstream and downstream firms, MNE bargaining power increased rather than obsolesced. The promised of additional technology transfers also kept the HC dependent on the MNEs and sustained the host country's interest in the potential benefits that the MNE could bring.

\section{The Political Bargaining Model}

We now turn to developing our proposed political bargaining model (PBM). We retain the core components of OBM but update them with recent insights from the international business (IB) and strategic management literatures. We break our analysis into the three core components of OBM: similarity of goals and relative states, resources and constraints, and finally, the bargaining outcome.

\section{$\underline{\text { Similarity of Goals and Relative Stakes }}$}

OBM assumes that both parties have goals they want to accomplish and that one party achieves goals that they believe salient at the expense of the other party. The (dis)similarity of interests between the two parties and the extent to which they frame their interests as zero sum affects the anticipated 
difficulty of the negotiations(Grosse \& Behrman 1992). The more similar the goals, the less difficult the bargaining process and the less need for the host government to regulate and/or coerce the MNE into activities seen as beneficial by the host country. MNEs and host governments tend to have dissimilar goals when they perceive that one will benefit at the expense of the other. OBM also assumes the MNE and HC's goals are inherently conflictual in nature. The conflict arises because MNEs are integrated businesses consisting of many affiliates located in a variety of countries, where all units are under common control and share common strategic goals and resources. Nation states, on the other hand, are the ultimate location-bound asset, limited in their sphere of action by geographic borders. Thus, MNEs and host countries are assumed to have divergent goals.

How would a political bargaining model reconceptualize the first component of OBM: the similarity of goals and relative stakes of the two parties?

MNE Goals. In OBM, the MNE has one of four specific motives for entry -- market seeking, resource seeking, efficiency seeking or strategic asset seeking -- as outlined by Dunning (1993b). For example, petroleum MNEs typically enter a host country looking for sources of oil (resource seeking) whereas white-goods (e.g. washing machines) MNEs typically are seeking new markets for their products. We identify two new issues in the IB literature related to MNE goals, and argue that these must be part of our new political bargaining model.

Recently, IB researchers have focused on MNEs from nontraditional home countries, such as emerging market firms (EMFs). The motives for internationalization of EMFs include not only market seeking (now referred to as knowledge exploitation FDI) but also knowledge seeking FDI. When MNEs go abroad to learn, rather than to exploit existing firm specific advantages, they enter a host country from a position of competitive disadvantage. Chung (2001), for example, showed that the technology spillover benefits to the United States were reduced when FDI entrants came from countries with average technology levels below US levels. Knowledge-seeking FDI is also the case for metanationals (Doz, Santos \& Williamson, 2002; Murtha, Lenway \& Hart, 2001) where their global competencies are derived from their abilities to learn from their affiliates located throughout the world. Second, underlying the 
MNE's specific motives for going abroad is a more diffuse set of objectives - improving economic efficiency, increasing its market power and obtaining legitimacy in the host country - that are needed if the MNE is to maximize its long-run after-tax global profits in the host country after entry (Boddewyn \& Brewer, 1994).

Efficiency and market power are well-understood terms but legitimacy may require some explanation. At the time of first entry, the MNE suffers from the liability of foreignness (Kostova \& Zaheer, 1999). Since the HC will lack familiarity or is likely to have stereotypical views about the MNE, the government will treat the MNE as an outsider, that is, as a firm without legitimate status in the host country. Legitimacy can be achieved if the MNE becomes isomorphic with the institutional environment in the host country; however, it takes time and commitment by the MNE to build a reputation and become recognized as an insider by the host country.

Legitimacy is also more likely to be enhanced when the MNE develops partnerships with local firms and institutions (Boddewyn \& Brewer, 1994) that make the firm 'become domestic', reducing liability of foreignness. These actions also can be related to stakeholder contract costs theory, where stakeholders exercise some social control over a firm (Wood, 1991). To manage these relationships, firms expend resources on social performance activities. Relational costs are lowered because stakeholders expect firms to deal fairly with respect to their rights and the overall distribution of outcomes. A firm that respects this implicit contract fosters social harmony and minimizes the costs of maintaining relationships with stakeholders (Jones, 1995). Firms with good social performance should realize lower costs of managing stakeholder relationships and thus earn higher financial returns than those firms with bad social practices. To the extent that the MNE can build organizational legitimacy in the host country through local partnerships and social performance activities, its potential bargaining power should atrophy less over time.

Third, the MNE's goals vis à vis the host country are affected by the activities that are shifted to that location and the position occupied by the foreign subsidiary(ies) within the MNE network. Traditionally, market-seeking and resource-seeking subsidiaries were established in developing countries, 
designed to either sell products locally or source local inputs to process or assembled elsewhere in the MNE network. As MNEs shift higher value-adding and more service-intensive activities offshore (e.g., the shifting of business processing functions to India or the Philippines), the changed nature of offshore activities should affect the MNE's goals and relative stakes.

HC Goals. In OBM, the host government's goals are different from the MNE's. The host government typically hopes to accomplish broader economic, social and political objectives through its negotiations with the foreign firm(s). Reflecting both nationalistic tendencies and rational economic attempts to secure greater benefits from foreign direct investment, the goals of developing country governments in the 1960 s and 1970s were seen as wanting significant investment and technology transfers, employment creation, positive balance of payments effects, local sourcing of inputs, etc.

Whereas the typical "host country" in OBM was a developing country such as Mexico or Brazil, in our PBM, "host countries" should probably be decomposed into four groups, each group with governments, which have different capabilities: developed market (e.g., United States), emerging (e.g., Brazil, South Korea, India), transition (e.g., former USSR members) and developing countries (e.g., Africa, Caribbean). Each group has its own institutions, cultures and goals. One would not expect the HC goals of the United States to be identical with those of emerging market economies, in terms of inward FDI. Our political bargaining model therefore needs to be nuanced to take into account the differing institutional characteristics capabilities and goals of host countries.

A second insight for PBM that comes from recent IB research is that government corruption can influence MNE-state relations. Petty/bureaucratic corruption, at the time of MNE entry, can influence the negotiation over investment concessions and tax incentives. The larger the number of bribe collectors, the greater the political hazards of negotiating with government officials. Public corruption deters inward FDI and influences companies' choice of entry mode (Rodriguez, Uhlenbruck and Eden, forthcoming).

(Dis)Similarity of MNE-HC Goals. In OBM, MNE and HC goals were seen as conflictual. In our political bargaining model, we argue MNE-HC goals do not have to be in conflict. The key point for PBM is that the goals of the two actors are different because MNEs and governments are very different 
entities with different objectives and a different geographic scope. Their goals may be in agreement, they may just be different, or they may actually conflict with one another. The important point is that there is some range of complementarity or overlap so that there is scope for each party to achieve its own goals through cooperation. (We are indebted to Steve Kobrin for clarifying this point.)

More recently, with widespread market liberalization and the pressures of globalization, HC goals have shifted toward the achievement of international competitiveness through the development of strong home bases. The work done over the past decade by Krugman, Porter and others on geographic clusters and agglomeration economies as drivers of innovation stresses that governments can help create more favorable business environments for domestic and foreign firms. "The unique and critical role of modern democratic governments is to create and sustain an efficient economic system”, which means that “governments and firms are best considered as partners in the wealth-creating process” (Dunning, 1997: 118,128). Because MNEs are now seen by governments as key actors in the process of transferring and facilitating international competitiveness, some IB scholars (e.g., Dunning, 1993a) argue that MNE-HC relations should now be viewed as cooperative rather than competitive, reflecting the shared goals of efficiency gains and international competitiveness. Where similarity of interests prevails, MNE-HC negotiations should be more harmonious, with both parties seeing benefits from combining the MNE's core advantages with the host country’s location-bound assets.

Size of the Stakes. The size of the stakes (how important the negotiations are to each party) can also affect MNE-HC bargaining and the outcome. While each party has general goals it hopes to accomplish, the importance each party attaches to the negotiations may differ. The stakes depend on the availability of alternatives to each party (i.e., the next best available alternative should deadlock occur), the importance of this particular negotiation to each party in the context of the overall MNE-HC relationship, and the importance of this negotiation in the context of each party’s overall interests.

In our political bargaining model, we recognize that numbers matter. As the number of MNEs continues to multiply, host countries should have more alternative sources of investment. The larger the host country, the smaller the importance attached to any single investment. Also, the number of suitable 
host countries has increased as countries have made institutional changes (or at least said they would) in response to new WTO rules liberalizing investments. For example, after 1996, the TRIPS (Trade Related Intellectual Property) accord requires governments to establish a domestic intellectual property rights regime, even if host governments find it difficult to enforce. Lastly, if we subdivide host countries into four groups (developed, emerging, transition and developing) the alternatives in terms of domestic and other sources of inward FDI are likely to vary considerably across the groups and across time. This suggests that the size of stakes to the HC will vary by the type of host country.

\section{$\underline{\text { Relative Resources }}$}

The second core component of OBM is the relative resources possessed by each party. In OBM, both parties are assumed to possess assets or resources that are valuable to the other. The MNE's resources are its firm specific assets (FSAs) that are difficult to imitate, such as patented technology, brand names and trade secrets (Teece, Pisano \& Shuen, 1997). The HC’s resources are the size of its local market and its country specific advantages (CSAs), typically subdivided into economic, sociocultural and political-legal (dis)advantages. We use recent insights from strategic management to update the concept of relative resources in our political bargaining model, as follows.

MNE Resources. Based on insights from the resource based view (RBV) of the firm, we argue that competitive advantage is derived from the firm's firm specific advantages (FSAs) or resources if they are rare, hard to imitate, have no direct substitutes, and enable companies to pursue opportunities or avoid threats (Barney, 1991). The firm's ability to earn sustainable above-normal rents (either Ricardian or monopoly rents) is dependent on its possession of heterogeneous resources, skills and capabilities, limits to industry competition, and imperfect factor mobility. We assume the MNE possesses three types of resources, based on the method by which they are protected from imitation: resources protected by property rights (including patents), tacit resources and relational resources.

Property-based resources are "enforceable long-run contracts that monopolize scarce factors of production, embody exclusive rights to a valuable technology, or tie up channels of distribution...they 
buffer an organization from competition by creating and protecting assets that are not available to rivals at least not under equally favorable terms” (Miller \& Shamsie, 1996:522). Exclusive ownership of a valuable resource that cannot be legally imitated by rivals means that its owner can earn superior rents on the resource. Any rival firm that wants the resource must pay the discounted future value of the expected economic returns from the resource.

Where FSAs are not protected by contracts, there are at least two other categories that may satisfy Barney’s resource definition. First, tacit resources, by definition, are subtle and hard to understand, based on routines and learning by doing. Because they are hard to transfer, their value is protected not by property rights but by knowledge barriers. Second, external relationships that facilitate knowledge sharing, privileged access to resources or customers, and/or erect barriers to entry may confer monopoly rents. These relation-based resources can arise through strategic alliances between firms or businessgovernment relationships. In this regard, Boddewyn (1988) argues that MNEs have political firm specific advantages that can be used to generate rents for the firm; one can see these as both tacit and relation based resources that favor firms with strong political ties to host country governments and stakeholders, reducing liability of foreignness and generating the ability to earn above-normal rents.

In sum, the MNE's resources/FSAs are its bundle of tangible and intangible assets that give rise to long-lived rents, where the MNE either owns property rights in the asset (or complementary assets) or its value is protected from erosion due to the tacit or relational-based nature of the asset.

HC Resources. The HC's resources, in OBM, are seen as its country specific advantages (CSAs): access to the local market, abundant raw materials, cheap labor, etc. With globalization, the increasing mobility of capital and the decreasing importance of traditional resources such as unskilled labor and raw materials, the host country's resources in our political bargaining model need to also be redefined, in the same way that FSAs have been redefined by the resource-based view of the firm. The host country's true locational advantages are its location-bound assets, in part derived from geography, that are rare, hard to imitate, have no direct substitutes, and enable firms using those resources to pursue opportunities or avoid threats. Governments can positively affect the value of their "home bases" through dynamic efficiency- 
enhancing investments and a regulatory environment that encourages technological upgrading, reduction of transaction costs, and openness to the global economy (Dunning, 1997).

MNE-HC Valuation. In OBM, the value of each party's resources is measured, not by its owner's evaluation, but by the other party's desire for those resources. The other party's valuation depends on the strength of desire/need for the particular resource and on what other alternatives are available should this negotiation fail. We retain this concept of valuing resources in terms of the other party's valuation in our political bargaining model, but update the concept of valuation to take account of institutional distance as a barrier to evaluation.

The concept of institutional distance can be a useful construct for evaluating the HC's resources from the perspective of the MNE. Kostova and Zaheer (1999) argue that the institutional distance between the home and host country affects the MNE's ability to achieve external legitimacy in the host country. Institutional distance refers to difference/similarity between the regulatory, cognitive, and normative institutions of the two countries (Kostova, 1996). Institutional distance should increase transaction costs, reduce the MNE's evaluation of HC resources, and discourage FDI into institutionally distant countries (Shaver \& Pederson; Eden \& Miller, forthcoming). When cognitive institutional distance is high, governments are likely to see the MNE in stereotypical terms, increasing the MNE's liability of foreignness and making it more difficult for political bargains to be reached.

Potential Bargaining Power. Bargaining power comes from the ability to withhold resources that the other party wants. We argue that a political bargaining model should incorporate insights from the resource based view. HC bargaining power is stronger when the host country has rare and location-bound CSAs that are desired by the MNE (e.g., central location in a region for efficient logistics, large and growing national market, valuable natural resources). MNE bargaining power is stronger when the HC wants FSAs that are inimitable and in scarce supply (e.g., sophisticated technology). This, it is the relative resources of the MNE vis à vis the HC that is the underlying determinant of potential bargaining power in each negotiation.

Luo (2001) argues that resource complementarity is also an important factor influencing potential 
bargaining power. The greater the perceived complementarity between the MNE's and host country's resources, the higher each will value the other's resources. In the absence of other alternatives, the greater will be their bilateral interdependence, the higher the salience each party will attach to the bargaining process, and the more attention each party will devote to MNE-state relations. In these circumstances, Luo expects more cooperative relations, higher benefits for the MNE and stronger firm performance in the host country.

\section{$\underline{\text { Relative Constraints }}$}

The third key component of the obsolescing bargain model is the effect of political and economic constraints placed on each party's actions. The exercise of potential bargaining power, which depends on each party's resources as valued by the other party, can be reduced by exogenous constraints. Constraints on HC bargaining power can be political (e.g., a weak, politically unstable government that lacks legitimacy or the HC's actions are restricted by international agreements) or economic (the HC suffers from balance of payments difficulties). Constraints on the MNE's bargaining power can also be political (previous commitments to the host or home country or legal restrictions on its activities) or economic (restrictions imposed on the subsidiary by its parent firm). Thus, constraints can be either internal (within the MNE and HC) or external (imposed by third parties or external institutions). How can we update constraints for our political bargaining model?

MNE Constraints. Transaction cost economics suggests that previous contracting arrangements can constrain current negotiations. Argyres and Liebeskind (1999) argue that previous contracts can cause governance inseparability, that is, an agent's past governance choices can restrict the range and type of governance mechanisms the agent can adopt in the future. This is because contracts are difficult to reverse; “a firm's contractual commitments tie it to specific other parties who have rights in relation to the firm” (Argyres \& Liebeskind, 1999: 52). Governance inseparability creates two problems for the agent: the inability to engage in governance switching (changing modes) or governance differentiation (adding new modes). Thus, in repeated negotiations with the same government, or in negotiations with new 
governments, the MNE's options may be limited by its prior agreements with the host country or with other governments and firms.

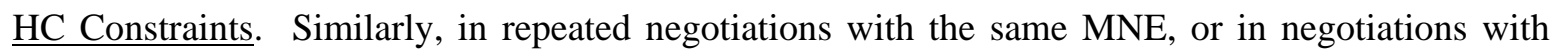
new MNEs, the host government may be constrained by its existing bargains. Bargains with one group of MNEs may constrain bargains with another group (Eden \& Molot, 2002). The actions of nongovernmental organizations, such as environmental and labor rights groups, can also constrain MNEstate bargains.

An important constraint not recognized in OBM is the role now played by supranational institutions in constraining the policies of national governments (Ramamurti, 2001). Because most developed and developing governments are members of multilateral organizations (e.g., World Trade Organization (WTO)), regulatory convergence through the multilateral rules negotiated between national governments now constrains MNE-HC bargaining. For example, the General Agreement on Trade in Services (GATS) requires member countries to schedule services for liberalization. While national treatment is not required by GATS, most favored nation (MFN) is required. To date, most developing countries have not scheduled very many services for liberalization under GATS.

Regulatory convergence is also fostered by bilateral and regional agreements. Bilateral investment treaties (BITs) guaranteeing right of establishment, national treatment, most favored nation (MFN) status, and so on, are now widespread. Bilateral tax treaties (BTTs) constrain excessive taxation of MNE subsidiaries by revenue-seeking nation states. Regional trade agreements such as the North American Free Trade Agreement (NAFTA) and the European Union regulate FDI flows within trading blocs. This web of binational and supranational agreements is creating an investment regime (Eden, 1996) that offers more protection, and bargaining leverage, to multinationals.

\section{The Bargaining Outcome}

Let us summarize the basic components of our political bargaining model. MNEs and nation states engage in political bargaining over a government policy that affects either the MNE directly or the 
industry of which it is a part. In the negotiations (which can include lobbying), the MNE seeks legitimacy and higher economic profits, and offers, in return for more favorable policies, improved access to the MNE's own non-location-bound resources (FSAs). The host government, as part of the policy negotiations, offers the MNE improved access to its location-bound resources (CSAs). The valuation each party places on the other's resources determines its potential bargaining power. The existence of economic, political and institutional constraints suggests that actual bargaining power may be greater or less than potential power, depending on several factors: the resources controlled by one party and demanded by the other, the similarity of interests and relative stakes attached to the negotiation, the constraints on each party, and the ability of either party to limit the behavior of the other party directly through economic or political coercion. The final outcome of the policy negotiations should tip in favor of the party with the strongest actual bargaining power. The 'winner' in the negotiations is defined by comparing the final outcome to the goals of each party; the one whose goals are most closely achieved is the winner. Both parties win if they believe the policy outcome will be ultimately beneficial for them.

\section{Discussion}

We argue that our political bargaining model is an improvement over the obsolescing bargain model in several dimensions.

First, PBM can handle a wider variety of issues in MNE-state relations than can OBM. In OBM, HC-MNE bargaining is over the initial firm-specific entry decision (e.g., FDI screening), subsequent monitoring of the MNE by the host government and the distribution of rents between the MNE and the HC. Our political bargaining model is conceptualized as much broader in scope. MNEs and governments bargain over a wide variety of government policies at the industry level; in some cases, individual firms will have very different policy positions, in others they may lobby as a group. Over time, through iterative bargaining, MNEs can affect government policies toward their industry, and in turn affect the achievement of MNE goals. Bargaining outcomes in these public policy debates should depend on the relative goals, resources and constraints of the two parties, as outlined above, with the "winner” being the 
party whose goals are most closely mapped by the outcome.

Second, OBM assumes that negotiations take place between one MNE and one host country government. However, the real world is much more likely to be characterized by negotiations among multiple MNEs, domestic firms and the government over a particular policy issue (Averyt \& Ramagopal, 1999; Keillor, Boller \& Ferrell, 1997). For example, Eden and Molot (2002) explored the effects of two waves of entrants (first movers and latecomers) into the Canadian auto industry. They found both groups suffered from the liability of foreignness of establishing operations in a foreign country. Each brought FSAs "to the table" at the time of entry and invested in resource-building strategies afterwards to overcome their liability of foreignness. In the case study, the first movers (the Big Three auto MNEs) achieved legitimacy as insiders in Canada and accumulate privileged access to markets and inputs. The subsequent entry of Asian auto MNEs disturbed the original MNE-HC bargain, and generated subsequent bargaining rounds where insiders and outsiders jockeyed for preferential treatment.

Third, PBM can contain OBM as a special case. Vernon's In the Eye of the Hurricane (Vernon, 1998) argues that MNE-state relations at the end of the 1990s were an unusual period of harmonious relations. He predicted that, in both developed and less developed countries, these relations would become more conflictual in the early years of the $21^{\text {st }}$ century. Both home and host country governments would be more likely to ask the MNEs in their midst, "What have you done for me lately?” and to either require greater commitments from these MNEs or response with less favorable government policies. Vernon's predictions may be coming to pass as governments new to MNEs (e.g., Russia) and governments well experienced with MNEs (e.g., Venezuela), have both in the past year, retaliated against the MNEs in their midst. Anti-MNE individuals and NGOs now regularly mount strong protests at meetings of international organizations such as the OECD, WTO, IMF and World Bank (Eden \& Lenway, 2001). Thus, the perception that all MNE-state relations are harmonious and MNE-state bargains never obsolesce is wishful thinking. There are cases where OBM can provide a useful theoretical lens. Thus, OBM can be seen as a useful but rare case within the general political bargaining model. 


\section{Conclusions}

The international business literature is full of individual case studies of the obsolescing bargain model, some supporting and some rejecting the hypothesis that MNE-HC relations are inherently conflictual and that MNE-HC entry bargains are bound to obsolesce. Even though scholars believe that OBM is dead, we have argued in this paper that core concepts from the model can and should be retained. We developed a new model - the political bargaining model (PBM) - using the concepts of goals, resources and constraints as a theoretical lens through which to examine MNE-state relations over time, and, indeed, other international business relationships. Our model takes into account recent insights from the international business and strategic management literatures as a way to revitalize research on MNEstate relations. We argue that PBM is a powerful theoretical lens for analyzing MNE-state relations, one that includes the obsolescing bargain model as a special case. We hope that the political bargaining model will turn out to be useful for other scholars in their research on public policy negotiations between MNEs and nation states. 
Table 1

From an Obsolescing Bargain to a Political Bargaining Model of MNE-State Relations

\begin{tabular}{|c|c|c|c|c|}
\hline & \multicolumn{2}{|c|}{ The Obsolescing Bargain Model } & \multicolumn{2}{|c|}{ The Political Bargaining Model } \\
\hline & MNE & HC & MNE & HC \\
\hline \multirow[b]{2}{*}{$\begin{array}{l}n \\
0 \\
0\end{array}$} & \multicolumn{2}{|c|}{$\begin{array}{l}\text { MNE-HC goals are conflictual but the } \\
\text { bargain is potentially positive sum (both } \\
\text { parties can gain). }\end{array}$} & \multicolumn{2}{|c|}{$\begin{array}{l}\text { MNE-HC goals are different and are typically } \\
\text { cooperative; there is positive sum bargaining. }\end{array}$} \\
\hline & $\begin{array}{l}\text { Market or } \\
\text { resource seeking } \\
\text { goals. }\end{array}$ & $\begin{array}{l}\text { Economic, social } \\
\text { and political goals, } \\
\text { focusing on } \\
\text { national welfare. }\end{array}$ & $\begin{array}{l}\text { MNE wants access to } \\
\text { HC’s location-bound } \\
\text { CSAs. Importance of } \\
\text { organizational legitimacy, } \\
\text { relative to efficiency and } \\
\text { market power goals. }\end{array}$ & $\begin{array}{l}\text { HC wants access to } \\
\text { MNE’s non-location- } \\
\text { bound FSAs. Goals } \\
\text { vary by type of host } \\
\text { country. Importance } \\
\text { of national } \\
\text { competitiveness. }\end{array}$ \\
\hline 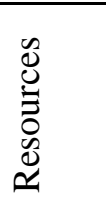 & $\begin{array}{l}\text { FSAs of the } \\
\text { MNE. FDI is a } \\
\text { bundle of capital, } \\
\text { technology and } \\
\text { managerial skills. }\end{array}$ & $\begin{array}{l}\text { CSAs of the host } \\
\text { country (economic, } \\
\text { social and political) } \\
\text { that attract FDI. }\end{array}$ & $\begin{array}{l}\text { MNE transfers non- } \\
\text { location-bound resources } \\
\text { that are property-based and } \\
\text { tacit/relational-based. }\end{array}$ & $\begin{array}{l}\text { HC offers location- } \\
\text { bound resources } \\
\text { (property-based and } \\
\text { relational-based). }\end{array}$ \\
\hline 剀 & \multicolumn{2}{|c|}{$\begin{array}{l}\text { Economic and political constraints, both } \\
\text { domestic and international. }\end{array}$} & \multicolumn{2}{|c|}{$\begin{array}{l}\text { Economic, political and institutional constraints. } \\
\text { Governance inseparability constrains outcomes. } \\
\text { International institutions and home country } \\
\text { governments can affect outcomes. }\end{array}$} \\
\hline 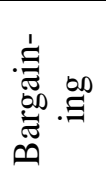 & \multicolumn{2}{|c|}{$\begin{array}{l}\text { Bargain over MNE entry. Subsequent } \\
\text { bargains with same firm(s) over access } \\
\text { to HC resources, contribution to HC and } \\
\text { ability to repatriate profits. }\end{array}$} & \multicolumn{2}{|c|}{$\begin{array}{l}\text { MNEs and governments bargain over public } \\
\text { policies in industry-specific issue areas. }\end{array}$} \\
\hline 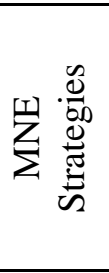 & \multicolumn{2}{|c|}{$\begin{array}{l}\text { Focus on preventing opportunistic } \\
\text { behavior by the host government. }\end{array}$} & \multicolumn{2}{|c|}{$\begin{array}{l}\text { MNEs use economic and political strategies, } \\
\text { lobbying for legitimacy in order to overcome } \\
\text { liability of foreignness. MNE-HC relations can be } \\
\text { strengthened through organizational legitimacy, } \\
\text { political accommodation, resource complementarity } \\
\text { and personal relations. }\end{array}$} \\
\hline 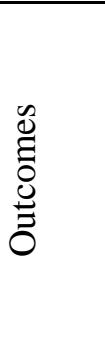 & \multicolumn{2}{|c|}{$\begin{array}{l}\text { Outcomes measured by percent of } \\
\text { ownership retained by the MNE. } \\
\text { Outcome depends on relative goals, } \\
\text { resources and constraints. Initial } \\
\text { bargains favor MNE and then obsolesce } \\
\text { over time. }\end{array}$} & \multicolumn{2}{|c|}{$\begin{array}{l}\text { Outcomes measured by which party most closely } \\
\text { achieves its goals. Outcome depends on the parties' } \\
\text { relative goals, resources and constraints. } \\
\text { Governance inseparability, firm rivalry and liability } \\
\text { of foreignness are key variables affecting } \\
\text { bargaining outcomes. Other governments and } \\
\text { international institutions are important intervening } \\
\text { variables. }\end{array}$} \\
\hline
\end{tabular}




\section{References}

Argyres, Nicholas and Julia Porter Liebeskind. 1999. Contractual commitments, bargaining power, and governance inseparability: incorporating history into transaction cost theory. Academy of Management Review 24: 49-63.

Averyt, William F. and K. Ramagopal. 1999. Strategic disruption and transaction cost economics: The case of the American auto industry and Japanese competition. International Business Review 8: 3953.

Barney, Jay. 1991. Firm resources and sustained competitive advantage. Journal of Management 17: 99-120.

Bennett, Douglas C. and Kenneth E. Sharpe. 1979. Agenda setting and bargaining power: The Mexican state versus transnational automobile corporations. World Politics 32: 57-89.

Boddewyn, Jean. 1988. Political Aspects of MNE Theory. Journal of International Business Studies, 19: 341-136.

Boddewyn, Jean and Thomas Brewer. 1994. International-business political behavior: new theoretical directions. Academy of Management Review 19: 119-44.

Brewer, Thomas. 1992. An issue area approach to the analysis of MNE-government relations. Journal of International Business Studies 23:295-309.

Chung, Wilbur. 2001. Identifying Technology Transfer in Foreign Direct Investment: Influence of Industry Conditions and Investing Firm Motives. Journal of International Business Studies, 2nd Quarter, 32.3: 211-229.

Doz, Yves, Jose Santos \& Peter J. Williamson. 2001. From Global to Metanational: How Companies Win in the Knowledge Economy. Cambridge, MA: Harvard Business School Press Books.

Dunning, John. 1997. Governments and the macro-organization of economic activity: A historical and spatial perspective. In Governments, Globalization and International Business, edited by John Dunning. Oxford and New York: Oxford University Press. 
Dunning, John. 1993a. Governments and multinational enterprises: From confrontation to cooperation? In Lorraine Eden and Evan Potter (eds.), Multinationals in the Global Political Economy. London: Macmillan.

Dunning, John. 1993b. Multinational Enterprises and the Global Economy. Reading, MA: AddisonWesley.

Eden, Lorraine. 1996. The Emerging North American Investment Regime. Transnational Corporations 5(3): 61-98.

Eden, Lorraine and Stefanie Lenway. 2001. Multinationals: The Janus Face of Globalization. Journal of International Business Studies, 32.3: 383-400.

Eden, Lorraine and Stewart Miller. Forthcoming. Distance Matters: Liability of Foreignness, Institutional Distance and Ownership Strategy. In M.A. Hitt \& J.L.C. Cheng (eds.), The Evolving Theory of the Multinational Firm. Advances in International Management. Volume 16, Elsevier, Amsterdam, Netherlands.

Eden, Lorraine and Maureen Appel Molot. 2002. Insiders, outsiders and host country bargains. Journal of International Management.

Grosse, Robert. 1996. The bargaining relationship between foreign MNEs and host governments in Latin America. The International Trade Journal 10: 467-99.

Grosse, Robert and Jack N. Behrman. 1992. Theory in international business. Transnational Corporations 1: 93-126.

Jenkins, Barbara. 1986. Re-examining the 'obsolescing bargain': A study of Canada's National Energy Program. International Organization 40: 139-65.

Jones, T.M. 1995. Instrumental stakeholder theory: A synthesis of ethics and economics. Academy of Management Review, 20: 404-437.

Keillor, Bruce D., Gregory W. Boller \& O. C. Ferrell. 1997. Firm-level political behavior in the global market place. Journal of Business Research 40: 113-26. 
Kobrin, Stephen. 1987. Testing the bargaining hypothesis in the manufacturing sector in developing countries. International Organization 41: 609-38.

Kostova, Tatiana. 1996. Success of the Transnational Transfer of Organizational Practices Within Multinational Companies. Unpublished doctoral dissertation, University of Minnesota.

Kostova, Tatiana and Srilata Zaheer. 1999. Organizational legitimacy under conditions of complexity: The case of the multinational enterprise. Academy of Management Review 24: 64-81.

Luo, Yadong. 2001. Toward a cooperative view of MNC-host government relations: Building blocks and performance implications. Journal of International Business Studies 32: 401-19.

Miller, Danny and Jamal Shamsie. 1996. The resource-based view of the firm in two environments: The Hollywood film studios from 1936 to 1965. Academy of Management Journal 39: 519-43.

Moran, Theodore, editor. 1985. Multinational Corporations: The Political Economy of Foreign Direct Investment. Lexington, MA: Lexington Books.

Moran, Theodore. 1973. Transnational strategies of protection and defense by multinational corporations: Spreading the risk and raising the cost for nationalization in natural resources. International Organization 27: 273-87.

Murtha, Thomas P., Stefanie Ann Lenway and Jeffrey A. Hart. 2001. Managing New Industry Creation: Global Knowledge Formation and Entrepreneurship in High Technology. Stanford: Stanford University Press.

Pederson, Torben and J. Myles Shaver. 2003. Internationalization Revisited: The Big Step Hypotheses. Working Paper.

Ramamurti, Ravi. 2001. The Obsolescing 'Bargain Model'? MNC-Host developing country relations revisited. Journal of International Business Studies, 32.1: 23-39.

Rodriguez, Peter, Klaus Uhlenbruck and Lorraine Eden. Forthcoming. Corrupt Governments Matter: How Corruption Affects the Entry Strategies of Multinationals. Academy of Management Review.

Stopford, John M. 1994. The growing interdependence between transnational corporations and governments. Transnational Corporations 3: 53-76. 
Teece, David J., Gary Pisano and Amy Shuen. 1997. Dynamic capabilities and strategic management. Strategic Management Journal 18: 509-33.

Vachani, Sushil. 1995. Enhancing the obsolescing bargain theory: A longitudinal study of foreign ownership of US and European multinationals. Journal of International Business Studies 26: 15980.

Vernon, Raymond. 1971. Sovereignty at Bay: The Multinational Spread of US Enterprises. New York: Basic Books.

Vernon, Raymond. 1977. Storm over the Multinationals: The Real Issues. Cambridge, MA: Harvard University Press.

Vernon, Raymond. 1998. In The Hurricane's Eye: The Troubled Prospects of Multinational Enterprises. Cambridge MA: Harvard University Press.

Wood, D.J. 1991. Corporate Social Performance Revisited. Academy of Management Review, 16(4), 691718.

Zaheer, Srilata. 1995. Overcoming the liability of foreignness. Academy of Management Journal, 38 : 341-63.

Zaheer, Srilata and Elaine Mosakowski. 1997. The dynamics of the liability of foreignness: A global study of survival in financial services. Strategic Management Journal, 18: 439-64. 